\title{
Impact of maternal undernutrition and fetal number on glucocorticoid, growth hormone and insulin-like growth factor receptor mRNA abundance in the ovine fetal kidney
}

\author{
K A Brennan, G S Gopalakrishnan, L Kurlak, S M Rhind ${ }^{1}$, C E Kyle ${ }^{1}$, A N Brooks ${ }^{2}$, M T Rae ${ }^{1}$, \\ D M Olson ${ }^{3}, \mathrm{~T}$ Stephenson and M E Symonds \\ Centre for Reproduction and Early Life, Institute of Clinical Research, Queen's Medical Centre, Nottingham NG7 \\ 2UH, UK, ${ }^{1}$ Macaulay Institute, Craigiebuckler, Aberdeen AB15 8QH, UK, ${ }^{2}$ Astrazeneca, Alderly Park, Cheshire \\ SK10 4TJ, UK and ${ }^{3}$ Perinatal Research Centre, University of Alberta, Edmonton T6G 2S2, Canada
}

Correspondence should be addressed to M E Symonds; Email: Michael.Symonds@nottingham.ac.uk

\begin{abstract}
Epidemiological and animal studies strongly indicate that the environment experienced in utero determines, in part, an individual's likelihood of developing cardiovascular disease in later life. This risk has been further linked to impaired kidney function, as a result of compromised development during fetal life. The present study therefore examined the influence of maternal nutrient restriction (NR), targeted at specific periods of kidney development during early to mid gestation, on the mRNA abundance of receptors for glucocorticoid (GCR), growth hormone (GHR) and insulin-like growth factors-I (IGF-IR) and -II (IGF-IIR), and the IGF-I and -II ligands. This was undertaken in both singleton and twin fetuses. At conception ewes were randomly allocated to either an adequately fed control group or one of four nutrient-restricted groups that were fed half the control amount from 0 to 30,31 to 65, 66 to110 or 0 to110 days gestation. At 110 days gestation all ewes were humanely euthanased and fetal kidneys and surrounding adipose tissue sampled. There was no effect of NR or fetal number on kidney weight, shape or nephron number, but the surrounding fat mass was increased in singleton fetuses exposed to NR for 110 days. An increase in kidney mRNA abundance with NR only occurred in singleton fetuses where IGF-IR mRNA was enhanced with NR from 66-110 days gestation. In twin fetuses, NR had no effect on mRNA abundance. However, for all genes examined mRNA expression was lower in the kidneys of twin compared with singleton fetuses following NR, and the magnitude of the effect was dependent on the timing of NR. In conclusion, the abundance of mRNA for receptors which regulate fetal kidney development are lower in twin animals compared with singletons following periods of nutrient deficiency. This may impact on later kidney development and function.

Reproduction (2005) 129 151-159
\end{abstract}

\section{Introduction}

Numerous studies have shown that the risk of developing several chronic diseases in adulthood, such as hypertension, can be affected by conditions experienced in utero. There is substantial epidemiological evidence that the nutritional and hormonal environment experienced by the fetus can determine the degree of adult risk (Barker 1998). It has also been well established that hypertension is linked to impaired kidney function for which reduced nephron number is one factor predisposing to increased risk of adult hypertension (Brenner et al. 1988). Maternal nutrient restriction (NR) can result in reduced growth factor abundance (Bauer et al. 1995) which would be predicted to compromise fetal organ development depending on the timing and duration of undernutrition.
The period of early to mid gestation coincides with the period of maximal placental growth in sheep and also represents a critical time in the formation of the fetal kidneys. In sheep, as in humans but unlike rodents, kidney development is completed and the adult nephron complement is reached before birth. The ovine pronephros develops and degenerates by day 30 of gestation (Wintour et al. 1996), near to the time of implantation. The ovine mesonephros first becomes functional at around day 16-18 of gestation and the full complement of nephrons is developed by around day 27-30. The organ then regresses by around day 57 of gestation (Wintour et al. 1996). At around 30 days gestation the ovine metanephros is made up of a mass of metanephric mesenchyme into which the ureteric bud has grown and branched once. Subsequent branchings of the ureteric duct induce the formation of 
new nephrons until around day 130 when the full nephron complement is complete (Moritz et al. 2003). The present study therefore targeted periods of NR up to 110 days gestation, a time when nephrogenesis would be proceeding at its maximal rate.

When maternal NR is targeted from 28-77 days gestation (ovine term is 147 days) there is an increase in glucocorticoid receptor (GCR) mRNA abundance in the kidneys and perirenal adipose tissue of newborn lambs (Whorwood et al. 2001). These kidneys are also larger than those from the control group and show changes in organ shape as well as having an increased surrounding fat mass (Bispham et al. 2003). This same period of NR has also been shown to affect the expression of insulin-like growth factor (IGF) -I and -II in both the liver and skeletal muscle without having any effect on organ weight (Brameld et al. 2000). IGFs have an important role in the normal development of the fetal kidney (Rogers et al. 1999) and the kidneys of growth retarded fetuses are much more sensitive to the effects of growth hormone $(\mathrm{GH})$ administration (Bauer et al. 2003) thus it is likely that maternal NR could compromise kidney development through local disruption of growth factor abundance. An increase in fat mass surrounding the kidney is also likely to have important later consequences as this can influence the local endocrine environment of the kidney and cause a direct physical constraint upon the kidney (Hall 2003). It has also been recently shown that as young adults, fetuses exposed to maternal NR for the first 95 days gestation have higher blood pressure than those fed to requirement (Gopalakrishnan et al. 2004a) in conjunction with reduced nephron number (Gopalakrishnan et al. 2004b).

In the present study we also investigated the potential effect of fetal number. Singleton and twin bearing mothers were therefore studied separately as the intrauterine environment experienced by twin fetuses is considerably different to that of singletons. For example, as the number of potential placentomes per mother is fixed, doubling the number of offspring normally means that each fetus has half the number of placentomes available compared with a singleton. This initially leads to an increase in individual placentome size (Symonds et al. 2000) in an attempt to compensate for reduced placentome number. Despite this adaptation twin fetuses are subject to an increased level of competition for available nutrients since they must compete both with the mother and their sibling. This may explain why previous studies have found that maternal NR can cause effects in twin fetuses that are not seen in singletons such as a precocious rise in fetal plasma adrenocorticotropic hormone (ACTH) concentration (Edwards \& McMillen 2002). Preliminary evidence indicates that kidneys from growth restricted twin fetuses have fewer nephrons than those of singleton animals (Mitchell et al. 2003) which could potentially put twins at greater risk of developing hypertension in adulthood.

The aim of the present study was to determine the effects of maternal NR, targeted at specific stages of fetal kidney development, on expression of GCR, GHR and the IGF receptors along with the IGF ligands together with nephron number and amount of adipose tissue surrounding the kidney. In addition we examined whether any effects were exacerbated in twin compared with singleton fetuses.

\section{Materials and Methods}

\section{Animals}

Fifty nine mature Scottish Blackface ewes were randomly allocated within body condition score class (range 2-3, on a scale of $0-5$; Russel et al. 1969) to one of five nutritional treatment groups. Ewes were individually housed under natural lighting conditions for several weeks before the day of mating. At 80 days of gestation ewes were scanned, using ultrasonography, to determine fetal number. All ewes were weighed and body condition scored every 21 days throughout the experiment and these results have been reported elsewhere (Rae et al. 2001). All operative procedures and experimental protocols had the required Home Office approval as designated by the Animals (Scientific Procedures) Act (1986).

\section{Maternal diet}

Ewes were initially fed diets estimated to provide the metabolisable energy (ME) requirement for liveweight maintenance (approximately $8.0 \mathrm{MJ}$ ME per day) or $50 \%$ of that amount. Rations were increased after day 80 of gestation by amounts designed to meet the requirements for fetal growth (or $50 \%$ of that amount) according to fetal burden, stage of pregnancy and treatment group (Robinson et al. 1983). The diet was comprised of concentrated pellet feed (Green Keil, Harbro Ltd, Turriff, UK) and hay, with access to water ad libitum. Animals ( $n=9-16$ per nutritional group) were fed as follows: group one were the control animals and received $100 \%$ of requirements throughout the experiment; groups $2-5$ were restricted to $50 \%$ of this amount from 0 to 30,31 to 65,66 to 110 and 0 to110 days gestation respectively and fed $100 \%$ at all other times. At 110 days gestation, ewes were killed by barbiturate overdose (Euthatal, $500 \mathrm{mg} \mathrm{ml}^{-1}, 30 \mathrm{ml}$ i.v.; Rhone Merieux, Harlow, UK). Fetal body, kidney and perirenal adipose tissue weights were taken and then kidney dimensions measured. At the same time, samples of fetal brain and gonads were sampled for later analysis that have been published elsewhere (Rae et al. 2001, Mühlhäusler et al. 2004), although the brains were not weighed. In the case of twins, one fetus per ewe was randomly selected and used for analysis. Organs were snap frozen in liquid nitrogen and stored at $-80^{\circ} \mathrm{C}$ for later analysis. In addition, all individual placentomes were dissected and weighed in order to calculate total placental mass for each fetus. 


\section{Messenger RNA analysis}

RNA was isolated from kidney tissue using Tri-Reagent (Sigma, Poole, UK) as previously described by Bispham et al. (2002). Messenger RNA abundance was then determined using RT-PCR using the following protocol: $94^{\circ} \mathrm{C}$ (2 min) 1 cycle, $94^{\circ} \mathrm{C}(30 \mathrm{~s})$, annealing temperature (as detailed in Table 1) $(30 \mathrm{~s}), 72^{\circ} \mathrm{C}(1 \mathrm{~min})$ for a fixed number cycles depending on the primers under test (see Table 1) and $72{ }^{\circ} \mathrm{C}$ (7 min) 1 cycle. The PCR mixture (final volume, $20 \mu \mathrm{l})$ contained $10 \times \mathrm{PCR}$ buffer $(100 \mathrm{mM}$ Tris- $\mathrm{HCl}$, $15 \mathrm{mM} \mathrm{MgCl} 2,500 \mathrm{mM} \mathrm{KCl}, \mathrm{pH}$ 8.3), $500 \mu \mathrm{M}$ dNTPs, $1 \mathrm{mM}$ of each primer and $3.75 \mathrm{U}$ Taq polymerase. Agarose gel electrophoresis $(2.0 \%)$ and ethidium bromide staining confirmed the presence of each gene under test plus $18 \mathrm{~S}$ products and that they were of the predicted size. Cycle number and annealing temperature were fully optimised for each primer pair and tissue prior to these studies as described in Table 1. All reactions were optimised to ensure that they were stopped before reaching the plateau stage and $18 \mathrm{~S}$ primer concentrations (added at a dilution of 1:5 to 1:10 depending on the expression level of the gene under test) were checked to ensure they were not limiting. All gels were run in triplicate with a standard included on each run. Densitometric analysis was then performed on each gel using advanced image detection analysis (Aida version 2.31; Raytek, Sheffield, UK) following image detection using a Fujifilm LAS-1000 cooled CCD camera (Fuji Photo Film Co. Ltd, Tokyo, Japan) and results, in arbitrary units, are expressed as a ratio of an $18 \mathrm{~S}$ rRNA internal control and internal standard. The identity of all PCR products was confirmed through sequencing.

\section{Nephron counts}

Determination of the total renal nephron complement was undertaken using an adaptation of a mild acid-hydrolysis method (Welham et al. 2002) as recently described for use in sheep (Gopalakrishnan et al. 2004b). In brief, two $1 \mathrm{~g}$ slices of renal tissue comprising approximately half of a fetal kidney, harvested from formal-fixed kidneys and from different kidney regions, were incubated in $1 \mathrm{M}$ hydrochloric acid for $30 \mathrm{~min}$ at $37^{\circ} \mathrm{C}$. Acid was removed and replaced with $50 \mathrm{mM}$ phosphate buffered saline (PBS; $\mathrm{pH}$ 7.4). The tissue was homogenised using a bench top homogeniser (Yellowline disperser; IKA Works Inc, Wilmington, NC, USA) and a $20 \mu \mathrm{l}$ sample was subsequently taken and placed on a slide and overlaid with a cover slip. Using a $\times 10$ objective lens, the number of glomeruli in the aliquot was counted in triplicate for the 2 slices from each sample. The six results were averaged and used to determine the total number of glomeruli in the sample and therefore the whole kidney. The intra- and inter-assay variations were $11 \%$ and $16 \%$, respectively.

\section{Statistical analysis}

Effect of dietary intake was analysed using a one way analysis of variance followed by a Tukey's post-hoc test (SPSS v 9.0, SPSS Inc. Woking, UK) for single and twin offspring separately. Differences between singles and twins in each group were assessed using a Mann-Whitney $U$ test.

\section{Results \\ Placental, fetal, kidney and perirenal adipose tissue weights}

There were no significant differences in fetal or kidney weight or in nephron number with nutritional group or fetal number (Table 2, Fig. 1). Similarly kidney dimensions (i.e. length, width and breadth) were unaffected by either maternal nutrition or fetal number (data not shown). The mass of adipose tissue surrounding the kidney was greatest in those singleton fetuses exposed to NR throughout the study with this group having more fat than the corresponding group of twins (Fig. 2a). As a result the ratio of perirenal fat to kidney weight was significantly greater in these singleton fetuses (Fig. 2b). Twins had a smaller mean placental weight per fetus than singleton animals in all nutritional groups (Table 2). However, this difference only reached significance in those animals that were nutrientrestricted during the period immediately before sampling.

Table 1 Primer sequences and locations used for detection of insulin-like growth factors IGF-I and IGF-II, their receptors (R), growth hormone receptor and glucocorticoid receptor using PCR and annealing temperatures.

\begin{tabular}{|c|c|c|c|c|}
\hline Primer set & Product & Primer sequences & Primer position & Annealing temp. $\left({ }^{\circ} \mathrm{C}\right)$ \\
\hline Insulin-like growth factor-I & $401 \mathrm{bp}$ & $\begin{array}{l}\text { F 5'-CCC ATC TCC CTG GAT TTC TT-3' } \\
\text { R 5'-ACA TCT CCA GCC TCC TCA GA-3' }\end{array}$ & $\begin{array}{c}(46-65) \\
(446-427)\end{array}$ & 58.6 \\
\hline Insulin-like growth factor-II & 248 bp & $\begin{array}{l}\text { F 5'-TCA CAG CAG GAA AGT CGA TG-3' } \\
\text { R 5 5'-GGC ACA GTA AGT CTC CAG CA-3' }\end{array}$ & $\begin{array}{c}(945-964) \\
(1192-1173)\end{array}$ & 59.4 \\
\hline Insulin-like growth factor-IR & 498 bp & $\begin{array}{l}\text { F 5'-GCC TCC AAC TTT GTC TTT GC- } 3^{\prime} \\
\text { R 5 5'-GCT GAA ATA CTC CGG GTT CA-3' }\end{array}$ & $\begin{array}{l}(278-297) \\
(765-746)\end{array}$ & 59 \\
\hline Insulin-like growth factor-IIR & 401 bp & $\begin{array}{l}\text { F } 5^{\prime} \text {-ACC GGC ACT TCA ACT ACA CC- } 3^{\prime} \\
\text { R 5 } 5^{\prime} \text {-ACT CAG AAT GAC GGC TTC GT- } 3^{\prime}\end{array}$ & $\begin{array}{c}(5-24) \\
(405-386)\end{array}$ & 60 \\
\hline Growth hormone receptor & 315 bp & $\begin{array}{l}\text { F 5'-ATG AAC CCA TCT GCA TGT GA-3' } \\
\text { R 5 5'-TTC AGT CTT CTC ATC AGG GTC A-3' }\end{array}$ & $\begin{array}{c}(943-962) \\
(1258-1236)\end{array}$ & 59.7 \\
\hline Glucocorticoid receptor & 150 bp & $\begin{array}{l}\text { F 5'-ACT GCC CCA AGT GAA AAC AGA-3' } \\
\text { R 5'-ATG AAC AGA AAT GGC AGA CAT T-3' }\end{array}$ & $\begin{array}{l}(402-421) \\
(552-527\end{array}$ & 59 \\
\hline $18 \mathrm{~S}$ & 324 bp & Ambion Classic II 18S Internal Standards Catalogue no. 1717 & & \\
\hline
\end{tabular}


Table 2 Fetal, kidney and placental weights. Values are expressed as means with their standard errors. Significant differences between singleton and twin animals exposed to the same nutritional regime indicated by different superscripts: $a$ vs $b, P<0.05 ; c$ vs $d, P<0.01$.

\begin{tabular}{|c|c|c|c|c|c|c|}
\hline \multirow[b]{2}{*}{ Period of NR } & \multicolumn{2}{|c|}{ Fetal weight } & \multicolumn{2}{|c|}{ Kidney weight } & \multicolumn{2}{|c|}{ Placental weight } \\
\hline & Single & Twin $^{+}$ & Single & Twin & Single & Twin \\
\hline Control & $2066 \pm 51(n=5)$ & $2038 \pm 188(n=4)$ & $9.0 \pm 0.4$ & $8.8 \pm 0.7$ & $703 \pm 63$ & $653 \pm 65$ \\
\hline $0-30$ & $2199 \pm 54(n=7)$ & $1906 \pm 206(n=2)$ & $9.4 \pm 1$ & $7.6 \pm 0.7$ & $685 \pm 43$ & $639 \pm 54$ \\
\hline $31-65$ & $2227 \pm 80(n=6)$ & $2027 \pm 36(n=6)$ & $8.5 \pm 0.3$ & $7.9 \pm 0.2$ & $642 \pm 40$ & $558 \pm 34$ \\
\hline $66-110$ & $2030 \pm 41(n=4)$ & $1910 \pm 50(n=9)$ & $7.9 \pm 0.8$ & $7.1 \pm 0.3$ & $639 \pm 17^{a}$ & $538 \pm 26^{b}$ \\
\hline $0-110$ & $1919 \pm 94(n=7)$ & $1861 \pm 70(n=9)$ & $7.5 \pm 0.2$ & $7.8 \pm 0.4$ & $699 \pm 53^{c}$ & $474 \pm 23^{\mathrm{d}}$ \\
\hline
\end{tabular}

${ }^{+}$in the case of twins only one twin per ewe was sampled.

\section{Messenger RNA abundance}

An effect of maternal NR on mRNA abundance in the fetal kidney was seen in singleton animals, where an increase in IGF-IR, but not IGF-I (Fig. 3), was shown by fetuses NR from 66 to 110 days gestation. There was no significant effect of NR on IGF-II, IGF-IIR (Fig. 4) or GCR (Fig. 5). It appeared that mRNA expression of GHR was increased relative to controls following NR from 0 to 30 days (Fig. 6). The $P$ value for this difference did not reach statistical significance $(P=0.06)$. No effect of NR was observed in twin animals.

The mean mRNA abundance for all genes examined was lower in the kidneys of twin compared with singleton fetuses but the difference was only statistically significant in groups that had been nutrient restricted (Figs 3-6). The magnitude of difference was dependent on the timing of the period of NR. A significant difference between singleton and twin animals for the period of $0-30$ days gestation was only seen for IGF-II mRNA abundance. The lack of a statistically significant effect with respect to the other genes may be a reflection of the small number of twins in this group. In the group of animals nutrient restricted from 31 to 65 days twins showed significantly reduced expression of GHR, IGF-I, IGF-IR and IGF-II but not IGF-IIR or GCR. However, there was no significant difference in GHR expression in those animals nutrient restricted either from 66 to 110 or from 0 to 110 days. Apart from IGF-I and -IIR in the 66-110 day group, mRNA expression of all the other genes examined showed significant differences between singleton and twin animals in these nutritional groups.

\section{Discussion}

The major finding of the present study is that, dependent on the timing of NR during early to mid gestation, expression of mRNA for IGF-I and -II, their receptors, plus GHR and GCR are significantly down regulated in twin fetuses. The timing of the nutritional challenge was an important determinant of which genes were down regulated, with a period of NR from conception up to 110 days gestation causing reduced abundance of all genes examined in twin fetuses. Critically, these effects were apparent in the absence of any effects on fetal or kidney weights or nephron number, but prolonged NR up to 110 days gestation did result in a greater fat mass surrounding the kidney in singleton compared with twin fetuses. There was also a significant difference in placental weight between singleton and twin fetuses in those animals nutrient restricted immediately before the period of sampling. This may have caused a further reduction in nutrient availability to the fetus, which might be linked to the greater effect of fetal number observed in these groups.

NR of singleton-bearing ewes targeted between 66 and 110 days gestation resulted in raised abundance of mRNA of IGF-IR in the fetal kidney, an effect not seen in twins. Both IGF-I and IGF-II act through this receptor to promote growth, however, no changes were seen in mRNA abundance for either ligand. The increased receptor abundance

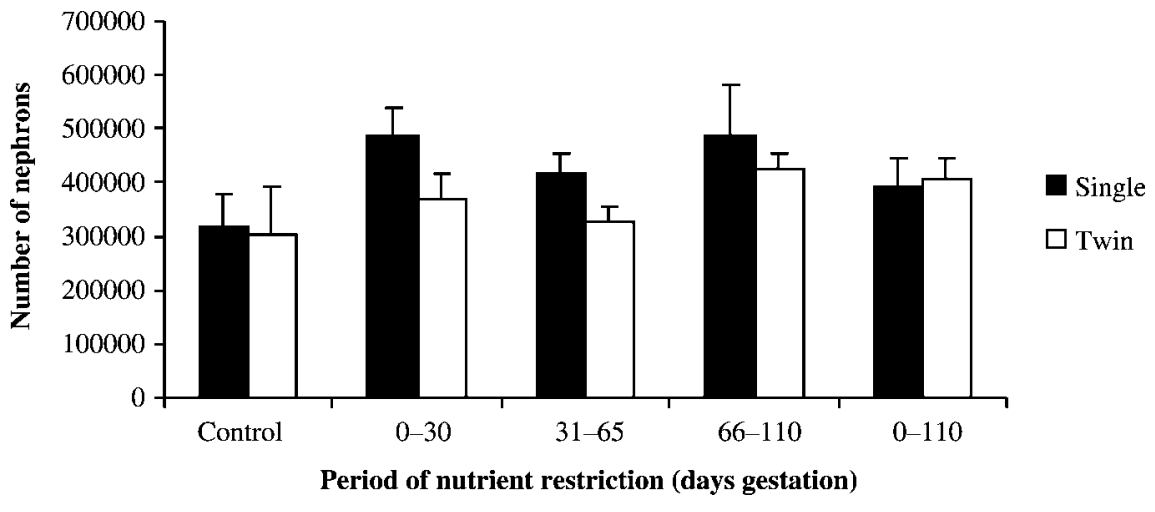

Reproduction (2005) 129 151-159
Figure 1 Nephron numbers in the kidneys of singleton and twin fetuses at 110 days gestation following maternal undernutrition at stages between early to mid gestation. Bar graphs illustrate means with their standard errors. 
(A)

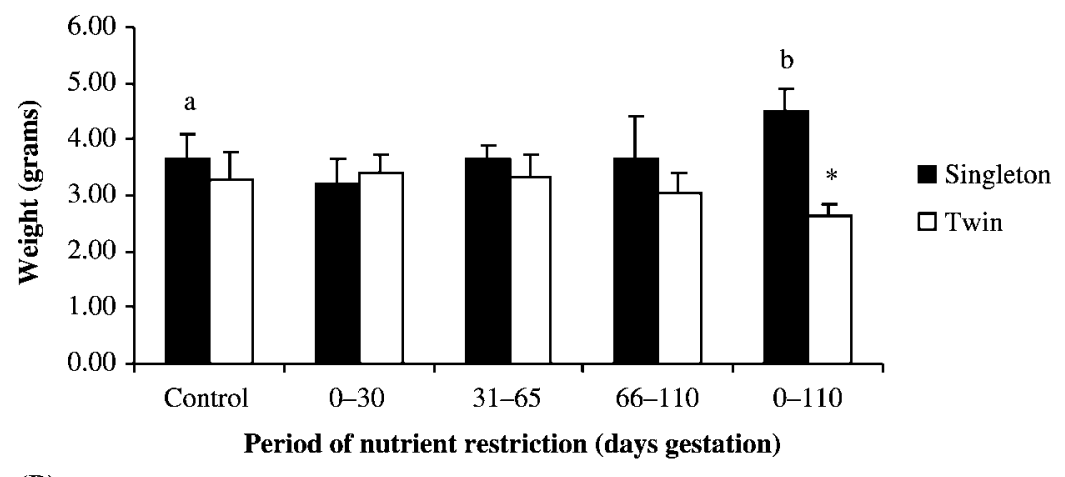

(B)

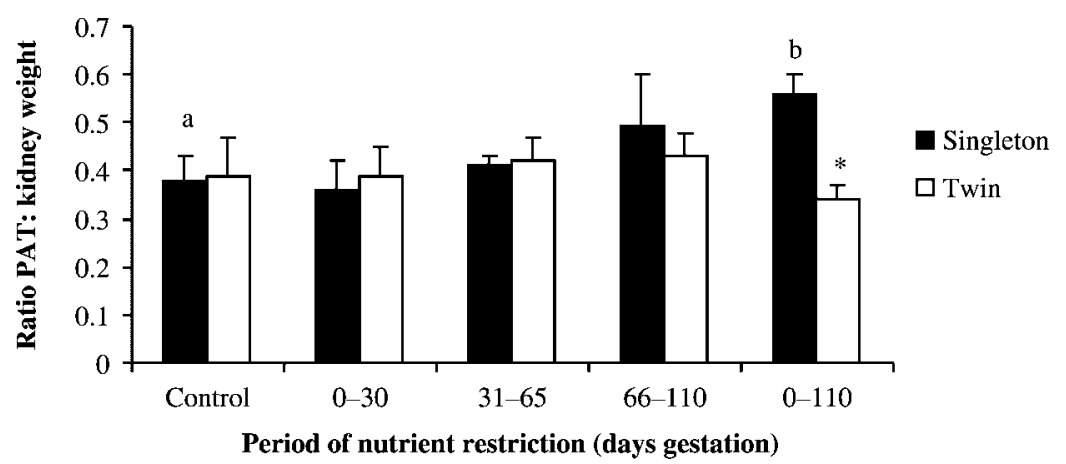

Figure 2 Effect of maternal undernutrition and fetal number on (a) perirenal adipose tissue weight and (b) the ratio of perirenal adipose tissue to kidney mass at 110 days gestation. Bar graphs illustrate means with their standard errors. Significant differences between singleton and twin animals exposed to the same nutritional regime indicated by * $P=0.001$ and differences between singleton nutritional groups indicated by different superscripts: a vs $b, P=0.056$.

could therefore lead to increased sensitivity to these hormones and potentially increase kidney growth rate. No change in kidney mass, size or nephron numbers was observed in the present study but previous work by Whorwood et al. (2001) found that NR between 28 and 77 days gestation resulted in larger kidneys that were surrounded by more fat (Bispham et al. 2003) and that 36 months of adult life nephron number was reduced (Gopalakrishnan et al. 2004b). These results are clearly in contrast with the findings of the present study, which indicates that the actual reduction in nephrogenesis seen in nutrient restricted fetuses occurs during the period of refeeding in later gestation. Similarly, alterations in the GH-IGF axis caused by earlier NR may affect an organ's growth rate later in gestation. Alternatively, it has been previously reported (Brameld et al. 2000) that maternal NR in early to mid gestation can reprogram the endocrine sensitivity of other organs without necessarily affecting fetal or organ weights. It is interesting to note that there was no up regulation of IGF-IR mRNA expression in singleton fetuses nutrient restricted from 0 to110 days gestation. It may therefore be, as has been shown with respect to the nutritional programming of fetal adipose tissue and liver development (Brameld et al. 2000, Bispham et al. 2003), that it is the switch from a nutrient restricted to an adequate diet that determines the magnitude of tissue endocrine sensitivity and any subsequent effects on organ mass (Whorwood et al. 2001, Bispham et al. 2003).

The lack of any effect of NR on the expression of IGF-IR in twins supports the hypothesis that twins respond very differently to undernutrition in a number of aspects. This includes the effect of periconceptional NR (i.e. from 60 days before mating to 8 days post mating), which has no detrimental effect on fetal growth in singletons but results in growth retardation in twins (Edwards \& McMillen 2002). These twin fetuses subsequently exhibit a greater increase in basal ACTH and cortisol in response to corticotrophic releasing factor infusion during late gestation. It remains to be established whether such effects are mediated as a consequence of adaptations within the fetus or mother, or both. The absence of any nutritional effect on IGF-IR mRNA in twins in the present study may be interpreted as reflecting a different maternal response to undernutrition dependent on fetal number. This may also contribute to the very different placental growth trajectories between singleton and twin pregnancies (Symonds et al. 2000). Although each twin has half the number of placentomes compared with singletons, these placentomes are twice as heavy (Mostyn et al. 1999). This adaptation is, however, not maintained up to term, resulting in total placental weights in twins that are nearly $50 \%$ lower than for a singleton of similar birth weight (Heasman et al. 1998).

A role for the GHR in fetal kidney development has not been established but it has been shown to be expressed at relatively high levels compared with other tissues such as liver and skeletal muscle (Ymer \& Herington 1992), suggesting that $\mathrm{GH}$ could be important in normal organogenesis. Previous work has found that infusing exogenous $\mathrm{GH}$ into normally growing sheep fetuses during late 
(A)

\section{IGF-I}
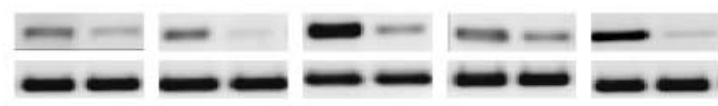

a

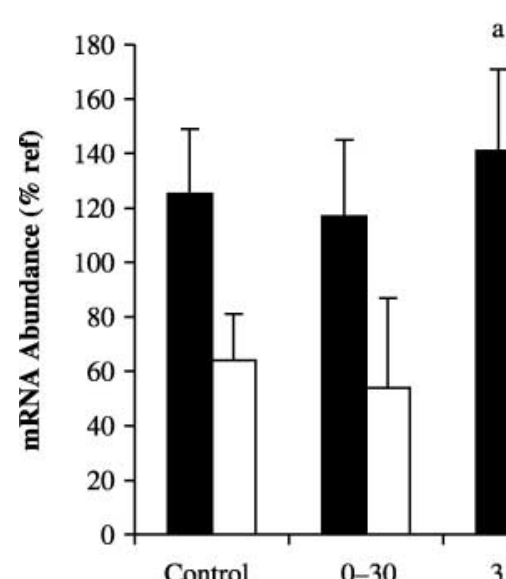

Control

\begin{abstract}
$0-30$
\end{abstract}

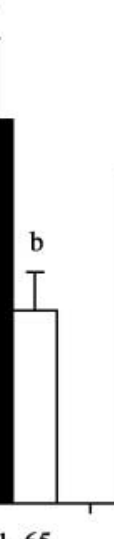

$31-65$

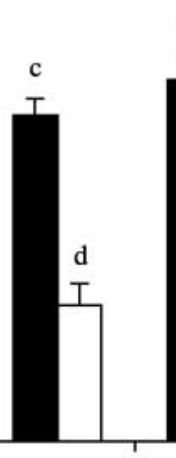

66-110

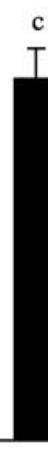

$0-110$

Period of nutrient restriction (days gestation)

(B)
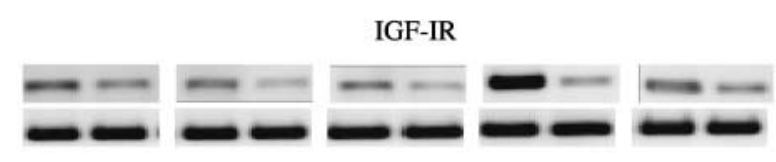

IGF-IR 498bp $18 \mathrm{~S} \quad 324 \mathrm{bp}$

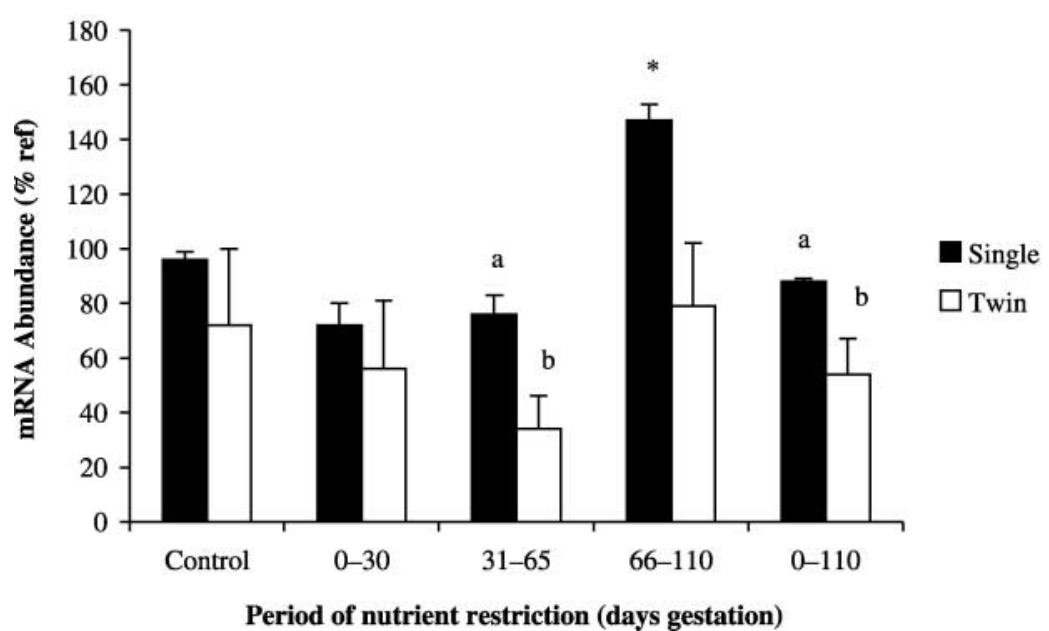

IGF-I $401 \mathrm{bp}$ $18 \mathrm{~S} 324 \mathrm{bp}$

\section{Single \\ $\square$ Twin}

Figure 3 Effect of maternal undernutrition and fetal number on expression of insulin-like growth factor (IGF)-I (A) ligand and (B) receptor (IGF-IR) mRNA abundance at 110 days gestation as measured using RT-PCR expression analysis. Examples of mRNA expression are given for each nutritional group. Bar graphs illustrate means with their standard errors. Significant differences between control and nutrient restricted (days 66-110) groups are indicated by $* P<0.01$ and significant differences between singleton and twin animals exposed to the same nutritional regime are indicated by different superscripts: a vs $b, P<0.05$; c vs $d, P<0.01$. gestation has no effect on renal development (Bauer et al. 2000). However, GH infusion into fetuses whose growth has been restricted by placental embolisation caused a significant decrease in kidney weight (Bauer et al. 2003). This suggests that the role GH plays in renal development may depend on the prevailing nutritional environment of the fetus. The fetuses in the present study did not show any signs of growth retardation at the time of sampling, although twin animals were consistently smaller. It is possible that the lower expression of GHR seen in twin animals' nutrient restricted from 31 to 65 days may affect the pattern of kidney development in those animals during later gestation.
Twin fetuses nutrient restricted for specific periods during pregnancy showed significantly lower expression of mRNA for IGF-I and -II than their singleton counterparts. Studies of knockout mice and experiments using metanephron culture systems (Wada et al. 1993, Rogers et al. 1999) have shown that these genes play an important role in kidney development, indeed mice lacking the IGF-I gene have proportionately smaller kidneys with fewer nephrons and reduced glomerular size. It is possible, therefore, that following NR kidney development in twins may not be as effective as in nutrient restricted singletons. The accompanying reduction in IGF-IRs expression in some of those twin groups would be likely 
(A)

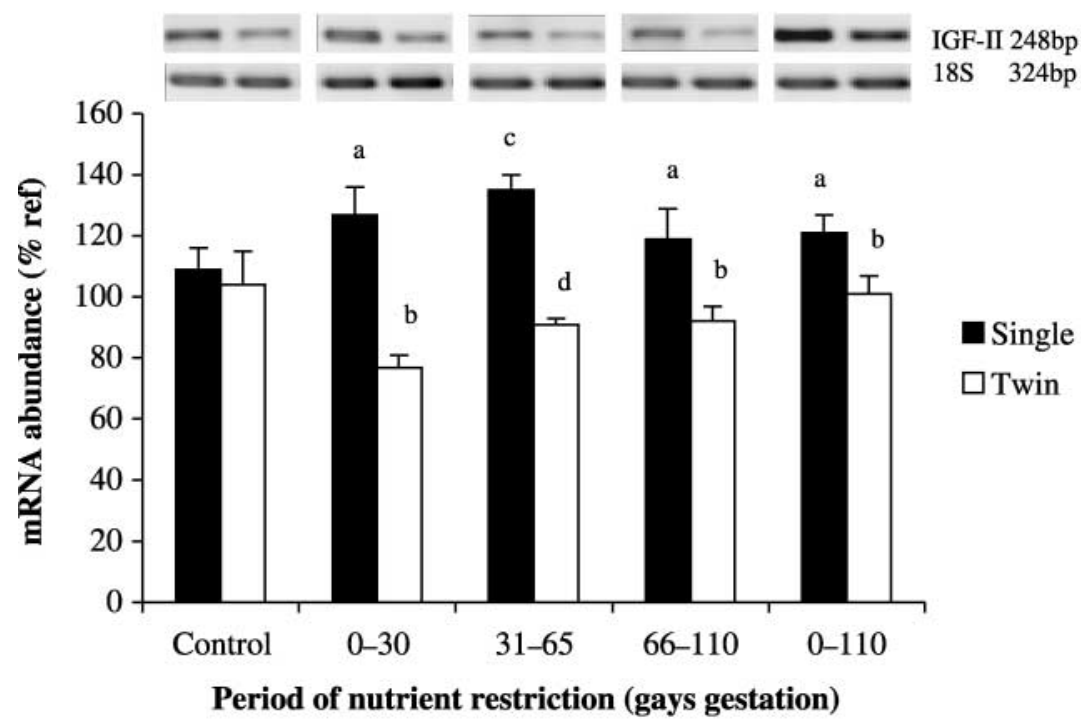

(B)

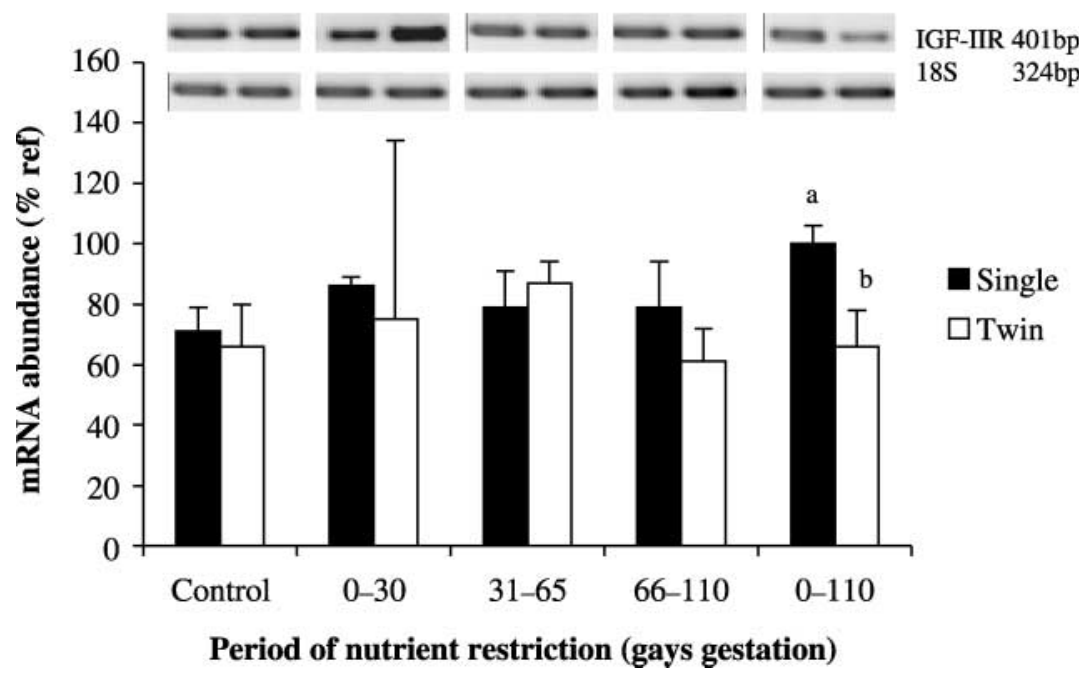

Figure 4 Effect of maternal undernutrition and fetal number on expression of insulin-like growth factor (IGF)-II (a) ligand and (b) receptor (IGF-IIR) mRNA abundance at 110 days gestation tissue as measured using RT-PCR expression analysis.

Examples of mRNA expression are given for each nutritional group. Bar graphs illustrate means with their standard errors. Significant differences between singleton and twin animals exposed to the same nutritional regime indicated by different superscripts: a vs b, $P<0.05$; c vs d, $P<0.01$. to exacerbate any effects. The twin fetuses of the group nutrient restricted from 0 to 110 days showed reduced expression of the IGF-IIR. This receptor is known to act as a scavenger removing IGF-II from the system (Hammerman 1989) so it is possible that this reduction may in some way compensate for the reduced expression of IGF-II in these animals. The extent to which the described changes in mRNA may be translated into parallel effects in protein abundance remains to be elucidated, but where measurements of both have been made in the ovine fetus these are highly correlated (Young et al. 2001).

Previous studies have found that NR in early to mid gestation followed by adequate feeding up to term led to an increase in the expression of GCR mRNA in the kidney of neonates (Whorwood et al. 2001). This adaptation was accompanied by a reduction in placental weight and concomitant decline in $11 \beta$ hydroxysteroid dehydrogenase type 2 activity. The lack of any effect on GCR abundance in the present study may be due to a difference in the timing of sampling. Alternatively, since placental weight was only reduced by NR in twins when the restriction was maintained after 66 days gestation, the relationship between $11 \beta$ hydroxysteroid dehydrogenase type 2 activity and placental development may be of greater importance with respect to subsequent GCR mRNA expression than nutrient availability per se.

In conclusion, maternal NR over the first 110 days of gestation has a time-dependent stimulatory effect on the expression of IGF-IR within the kidney. This effect is not found in twin fetuses which may relate to the very 
GHR

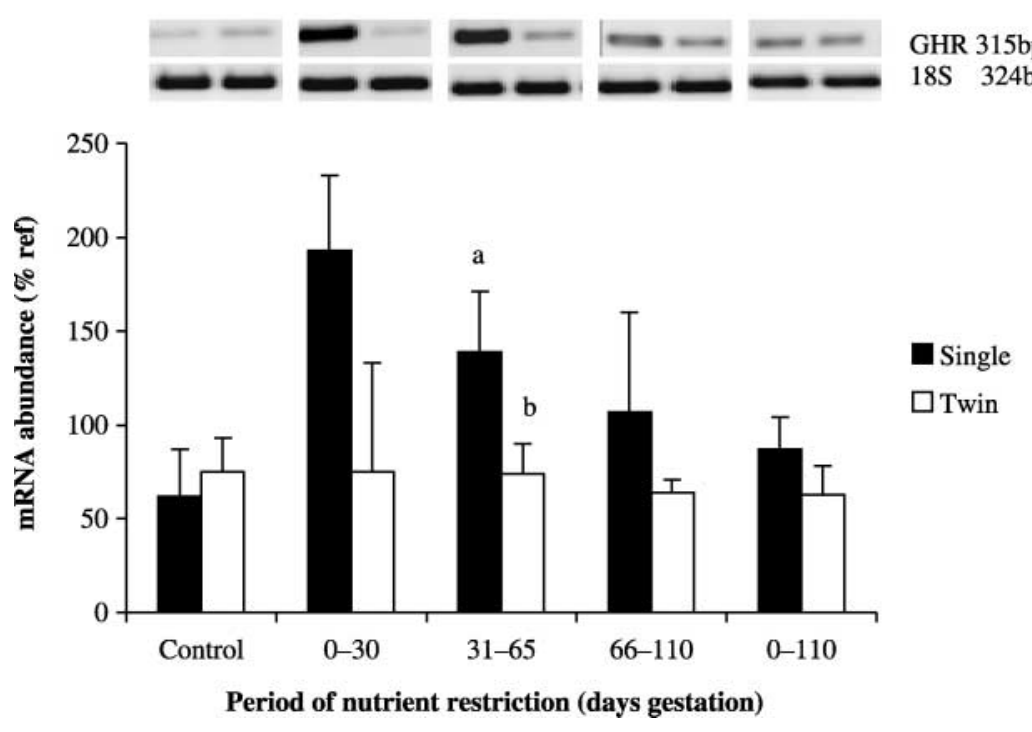

Figure 5 Effect of maternal undernutrition and fetal number on expression of glucocorticoid receptor (GCR) mRNA abundance at 110 days gestation as measured using RT-PCR expression analysis. Examples of GCR mRNA expression are given for each nutritional group. Bar graphs illustrate means with their standard errors. Significant differences between singleton and twin animals exposed to the same nutritional regime indicated by different superscripts: a vs b, $P<0.05$; c vs d, $P<0.01$.

\section{GCR}
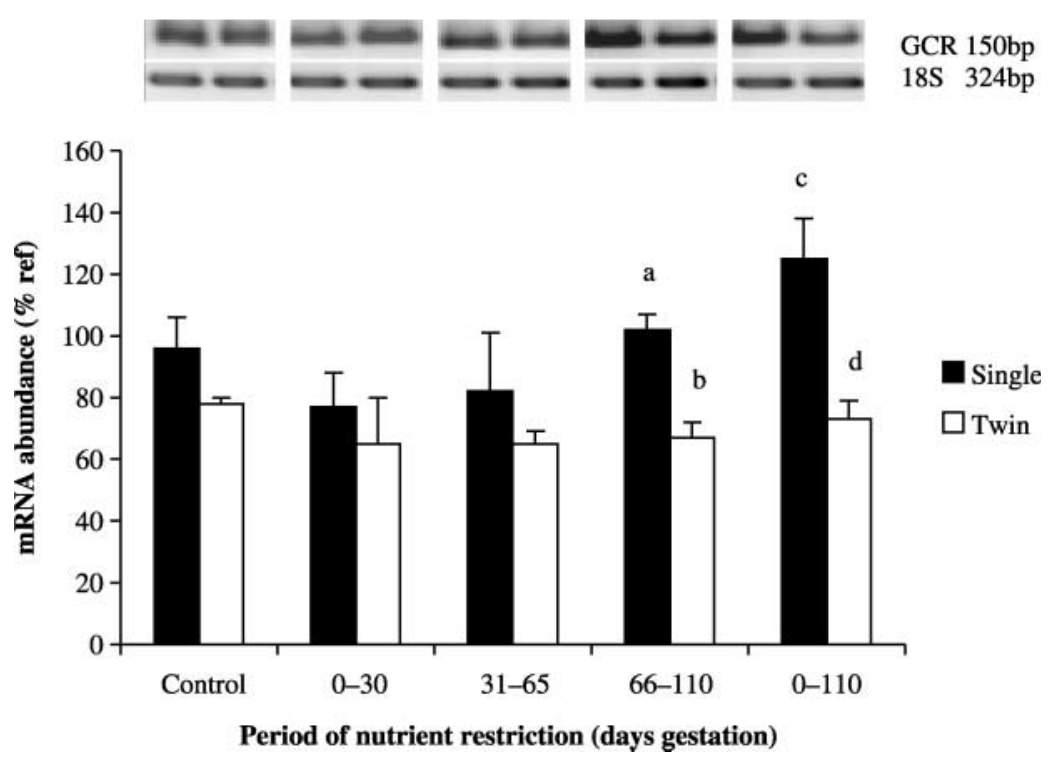

Figure 6 Effect of maternal undernutrition and fetal number on expression of growth hormone receptor (GHR) mRNA abundance at 110 days gestation as measured using RT-PCR expression analysis. Examples of GHR mRNA expression are given for each nutritional group. Bar graphs illustrate means with their standard errors. Significant differences between singleton and twin animals exposed to the same nutritional regime indicated by different superscripts: a vs $b, P<0.01$.

different maternal endocrine environment between singleand twin-bearing mothers (Budge et al. 2003), that only contributes to an up regulation of specific mRNA abundance during NR. The greatest differences between singleton and twin fetuses with respect to all genes examined were apparent when the mothers were nutrient restricted up to 110 days gestation. This adaptation was accompanied by a greater fat mass around the kidney which, in conjunction with a subsequent reduction in nephron number, could contribute to the higher blood pressure observed at three years of age in offspring nutrient restricted over a comparable period of pregnancy (Gopalakrishnan et al. 2004a).

\section{Acknowledgements}

$K A B$ was supported by postgraduate studentships from the University of Nottingham and the Canadian Institutes of Health Research. GSG was supported by a British Heart Foundation Studentship.

\section{References}

Barker D 1998 Mothers, Babies and Disease in Later Life, 2nd ed. Edinburgh: Churchill Livingstone.

Bauer MK, Breier BH, Harding JE, Veldhuis JD \& Gluckman PD 1995 The fetal somatotropic axis during long-term maternal undernutrition in sheep - evidence for nutritional regulation inutero. Endocrinology 136 1250-1257. 
Bauer MK, Harding JE, Breier BH \& Gluckman PD 2000 Exogenous $\mathrm{GH}$ infusion to late-gestational fetal sheep does not alter fetal growth and metabolism. Journal of Endocrinology $\mathbf{1 6 6}$ 591-597.

Bauer MK, Breier B, Bloomfield F, Jensen E, Gluckman PD \& Harding J 2003 Chronic pulsatile infusion of growth hormone to growth-restricted fetal sheep increases circulating fetal insulin-like growth factor-I levels but not fetal growth. Journal of Endocrinology 177 83-92.

Bispham J, Budge H, Mostyn A, Dandrea J, Clarke L, Keisler DH, Symonds ME \& Stephenson T 2002 Ambient temperature, maternal dexamethasone, and postnatal ontogeny of leptin in the neonatal lamb. Pediatric Research 52 85-90.

Bispham J, Gopalakrishnan GS, Dandrea J, Wilson V, Budge H, Keisler DH, Broughton Pipkin F, Stephenson T \& Symonds ME 2003 Maternal endocrine adaptation throughout pregnancy to nutritional manipulation: consequences for maternal plasma leptin and cortisol and the programming of fetal adipose tissue development. Endocrinology 144 3575-3585.

Brameld JM, Mostyn A, Dandrea J, Stephenson TJ, Dawson JM, Buttery PJ \& Symonds ME 2000 Maternal nutrition alters the expression of insulin-like growth factors in fetal sheep liver and skeletal muscle. Journal of Endocrinology 167 429-437.

Brenner BM, Garcia DL \& Anderson S 1988 Glomeruli and blood-pressure - less of one, more the other. American Journal of Hypertension $1335-347$.

Budge H, Dandrea J, Mostyn A, Evens Y, Watkins R, Sullivan C, Ingleton P, Stephenson T \& Symonds ME 2003 Differential effects of fetal number and maternal nutrition in late gestation on prolactin receptor abundance and adipose tissue development in the neonatal lamb. Pediatric Research 53 302-308.

Edwards LJ \& McMillen IC 2002 Impact of maternal undernutrition during the periconceptional period, fetal number, and fetal sex on the development of the hypothalamo-pituitary adrenal axis in sheep during late gestation. Biology of Reproduction $\mathbf{6 6}$ $1562-1569$.

Gopalakrishnan G, Gardner DS, Rhind SM, Rae MT, Kyle CE, Brooks AN, Walker RM, Ramsay MM, Keisler DH, Stephenson T \& Symonds ME 2004a Programming of adult cardiovascular function after early maternal undernutrition in sheep. American Journal of Physiology 287 R12-R20.

Gopalakrishnan G, Gardner DS, Kurlak LO, Langley-Evans SC, Rhind SM, Rae MT, Kyle CE, Stephenson T, Symonds ME \& Budge H 2004b Programming of nephron number in adult sheep by maternal nutrient restriction in early gestation. Proceedings of the Journal of Physiology (In Press).

Hall JE 2003 The kidney, hypertension, and obesity. Hypertension 41 625-633.

Hammerman MR 1989 The growth hormone insulin-like growth-factor axis in kidney. American Journal of Physiology 257 F503-F514.

Heasman L, Clarke L, Dandrea J, Stephenson T \& Symonds ME 1998 Correlation of fetal number with placental mass in sheep. Contemporary Reviews in Obstetrics and Gynaecology 10 275-280.

Mitchell EK, Louey S, Harding R, Cock ML \& Black MJ 2003 Growth retardation in utero due to twinning: effect on nephron endowment. Pediatric Research 53 Suppl 46A.
Moritz KM, Dodic M \& Wintour EM 2003 Kidney development and the fetal programming of adult disease. Bioessays 25 212-220.

Mostyn A, Dandrea J, Bispham J, Stephenson T \& Symonds ME 1999 Effect of fetal number on placental growth and placentome size in early to mid gestation in sheep. Journal of Physiology, London $\mathbf{5 1 7}$ 40P.

Mühlhäusler BS, McMillen IC, Rouzaud G, Findlay PA, Marrocco E, Rhind SM \& Adam CL 2004 Appetite regulatory neuropeptides are expressed in the sheep hypothalamus before birth. Neuroendocrinology 16 502-507.

Rae MT, Palassio S, Kyle CE, Brooks AN, Lea RG, Miller DW \& Rhind SM 2001 Effect of maternal undernutrition during pregnancy on early ovarian development and subsequent follicular development in sheep fetuses. Reproduction 122 915-922.

Robinson JJ, Russel AJF, Treacher TT \& Kilkenny JB 1983 In Feeding the ewe. Milton Keynes, Meat and Livestock Commission Sheep Improvement Services, pp 1-60.

Rogers SA, Powell-Braxton L \& Hammerman MR 1999 Insulin-like growth factor I regulates renal development in rodents. Developmental Genetics 24 293-298.

Russel AJF, Doney JM \& Gunn RG 1969 Subjective assessment of body fat in live sheep. Journal of Agricultural Science, Cambridge $72451-454$

Symonds ME, Budge H \& Stephenson T 2000 Limitations of models used to examine the influence of nutrition during pregnancy and adult disease. Archives of Disease in Childhood 83 215-219.

Wada J, Liu ZZ, Alvares K, Kumar A, Wallner E, Makino H \& Kanwar YS 1993 Cloning of cDNA for the alpha-subunit of mouse insulin-like growth factor-I receptor and the role of the receptor in metanephric development. PNAS 90 10360-10364.

Welham SJ, Wade A \& Woolf AS 2002 Protein restriction in pregnancy is associated with increased apoptosis of mesenchymal cells at the start of rat metanephrogenesis. Kidney International 61 $1231-1242$.

Whorwood CB, Firth KM, Budge H \& Symonds ME 2001 Maternal undernutrition during early to mid gestation programs tissuespecific alterations in the expression of the glucocorticoid receptor, 11 beta-hydroxysteroid dehydrogenase isoforms, and type 1 angiotensin II receptor in neonatal sheep. Endocrinology 142 2854-2864.

Wintour EM, Alcorn D, Butkus A, Congiu M, Earnest L, Pompolo S \& Potocnik SJ 1996 Ontogeny of hormonal and excretory function of the meso- and metanephros in the ovine fetus. Kidney International 50 1624-1633.

Ymer SI \& Herington AC 1992 Developmental expression of the growth-hormone receptor gene in rabbit-tissues. Molecular and Cellular Endocrinology 83 39-49.

Young L, Fernandes K, McEvoy T, Butterwith S, Gutierrez C, Carolan C, Broadbent P, Robinson J, Wilmut I \& Sinclair K 2001 Epigenetic Change in IGF2R is associated with fetal overgrowth after embryo culture. Nature Genetics 27 153-154.

Received 9 March 2004

First decision 12 May 2004

Revised manuscript received 28 September 2004

Accepted 14 October 2004 